\title{
Article \\ Effect of Raising Dairy Heifers on Their Performance and Reproduction after 12 Months
}

\author{
Michal Uhrincat (D), Jan Broucek*(D), Anton Hanus and Peter Kisac \\ National Agricultural and Food Centre, Research Institute of Animal Production Nitra, 95141 Luzianky, Slovakia; \\ michal.uhrincat@nppc.sk (M.U.); anton.hanus@nppc.sk (A.H.); pkisac1@gmail.com (P.K.) \\ * Correspondence: jan.broucek@nppc.sk
}

check for updates

Citation: Uhrincat, M.; Broucek, J.; Hanus, A.; Kisac, P. Effect of Raising Dairy Heifers on Their Performance and Reproduction after 12 Months. Agriculture 2021, 11, 973. https:// doi.org/10.3390/agriculture11100973

Academic Editors: Dejan Škorjanc and Manja Zupan Šemrov

Received: 19 August 2021

Accepted: 4 October 2021

Published: 7 October 2021

Publisher's Note: MDPI stays neutral with regard to jurisdictional claims in published maps and institutional affiliations.

Copyright: (c) 2021 by the authors. Licensee MDPI, Basel, Switzerland. This article is an open access article distributed under the terms and conditions of the Creative Commons Attribution (CC BY) license (https:// creativecommons.org/licenses/by/ $4.0 /)$.

\begin{abstract}
The objective of this study was to test the hypotheses that a heifer's growth, health, and reproduction after 12 months are impacted by rearing (feeding/housing) before weaning, their season of birth, and the father's lineage. Fifty-one Holstein heifers, born during January-March (SB1), April-June (SB2), July-September (SB3), and October-December (SB4) and originating from four fathers, were assigned to one of the three rearing treatments: restricted suckling (RS), calf in a pen with the mother until the 21st day, sucking three times daily, then group pen (6 kg milk) to weaning; unrestricted suckling (US), calf in a pen with foster cows (6 kg milk) to weaning; and conventional rearing (CR), calf in a hutch until the 56th day, then group pen to weaning (milk replacer $6 \mathrm{~kg}$ ). After weaning on the 84th day, heifers were kept in groups with the same ration. The growth of the live body weight (LBW), health, and reproduction were recorded. The LBW had a tendency to increase from the 360th to the 570th days in the US, and the reduced growth of the LBW was shown in the CR. Heifers of SB2 had the highest LBW at 570 days of age. The ages of the first insemination service and the conception varied significantly among the rearing groups. The results indicate that a heifer rearing method may have a significant impact on their later growth and fertility.
\end{abstract}

Keywords: livestock farming; dairy cattle welfare; raising; environment; production; fertility

\section{Introduction}

A variety of methods and facilities can be used to raise a replacement dairy animal. In husbandry, the method of separating a cow and their calf shortly after birth has been used for many years, but early weaning from the mother has been shown to affect normal behavioural development with later challenges of environment conditions [1,2]. It is expected that the delayed separation of the calf from its mother may improve the welfare and growth of dairy calves [3-6]. However, reducing the age at which calves are weaned is more cost effective when saving milk and milk replacer (MR) than delayed weaning.

A number of studies have explored keeping cows and calves together and examined the benefits of this natural rearing system $[4,7,8]$. The suckling systems can be divided into more categories depending on the farming purpose and duration of the suckling period on restricted (also referred to as a single suckling system) and the foster cow system (also referred to as multiple or cow-calf contact system) $[1,6,9,10]$. Restricted suckling means that the calf is allowed to suckle its own dam during short periods daily [11-14]. In the foster cow system, the calves are kept together and suckle one cow $[1,7,8]$.

However, we must distinguish between milk feeding or milk replacer (MR). Milk is more important in terms of nutrition, normal behaviour [9,10,15-17], and later performance of heifers $[18,19]$. The prolonged period of fostering and the social facilitation and social learning may result in increased concentrate and hay intake, and higher average daily gains (ADG) after weaning compared with individually kept calves [20-23]. These benefits from suckling period persisted for up to 16 months after separation $[2,6,24]$.

The authors of [25-28] showed that environmental factors affect both prenatal and postnatal life. The season of the year and status of reproductive cycles could have a big 
impact on when animals become sensitive to increasing heat loads [29]. Exposure to prenatal maternal stressors (hyperthermia) during foetal development can alter postnatal phenotypes and the expression of the genetic potential of the offspring [30-37]. The utero heat stress leads to lower birth weight and LBW at one year of age as well [38-41].

The aim of the present study was to objectively quantify the effects of rearing, the season of birth and the father's lineage on the growth rate, health condition, number of services to conception, and the percentage of conception after the first insemination of dairy heifers.

\section{Materials and Methods}

The study was performed in Nitra, Slovakia. It was the continuation of a long-term experiment, the first part of which was published last year [42], and evaluated the growth and health condition of calves under the age of 360 days. The present study examines the growth and reproduction of heifers from 361 to 570 days of age.

\subsection{Animals and Treatments}

The treatment of the animals was approved by the Ministry of Agriculture and Rural Development of the Slovak Republic, no. 115/1995 Z.z. and 377/2012 Z.z. The experiments were carried out in accordance with the Code of Ethics of the EU Directive 2010/63/EU for animal experiments.

At birth, 51 Holstein heifers were consecutively assigned to the three rearing treatments groups, balancing for birth weight. Calves in all groups were kept in an individual pen with the mother and received colostrum for the first 24 hours by suckling ad libitum. If some calves did not want to suckle, they were fed with a teat-bottle (two hours after the birth). A total of 11 calves received milk from the bottle ( $R S=4, \mathrm{US}=3$, and $\mathrm{CR}=4$ ). From the 2nd day until weaning, the calves were offered a starter mixture (SM) and alfalfa hay as a free choice. Three rearing treatments groups were observed (restricted suckling, unrestricted suckling, and conventional rearing). The calves in the group of a restricted suckling of dam (RS, $n=18)$ were kept separately in an individual pen $(4.5 \times 4.5 \mathrm{~m})$ with the mother (milked from the 2nd day at 05:00 and 16:00) until the 21st day, suckling a mother's udder 10 min 3 times per day (8:00, 13:00, and 18:00). Each calf had its own mother, not a random cow. The cow and the calf were loose. A small part of the pen was separated to be used by the calf $(1.2 \times 4.5)$ (Figure 1$)$. The separated part of the pen opened and the calf was released to its mother. From the 22nd day, the heifers were kept in a loose housing pen ( $6 \mathrm{~kg}$ any cow milk per day, $2 \times$ daily $3 \mathrm{~kg}$, bucket with nipple). The suckling time of a mother's udder $(3 \times 10 \mathrm{~min})$ was determined during preparation for the experiment according to Passille de and Rushen [43]. In the current phase of the experiment, these RS heifer calves were weighed before and after each suckling.

The calves in the group of unrestricted suckling of the foster cow (US, $n=16$ ) were kept for 3 days with their own mother in an individual pen and then a pen with non-milked foster cows from the 4th day to weaning. A foster cow is also referred to as a nursing cow (a cow that nurses alien calves). The heifer calves could suckle at any time, usually 3-5 times per day. A total of 8 cows were used, of which 3 were for the 2nd parity, 4 were for the 3rd parity, and 1 was for the 4th parity. Five cows were in the mid-lactation stage, and three were in the late lactation stage. Foster cows were selected (not randomly) from milking cows of the herd, with the main criteria being milk yield and the ability to accept an alien calf and to be nursed. The distribution of fostered calves by all eight cows was as follows: $1=2,2=1,3=4,4=2,5=1,6=1,7=2$, and $8=3$. Heifer calves of the US group suckled colostrum and the mother's milk ad libitum three times a day $(3 \times 10 \mathrm{~min} /$ day $)$ from the second to the third days. They suckled milk of foster cows from the 4th day (suckle at any time) to weaning. The number of US calves per foster cow was determined according to milk yield of the selected cows, ensuring that $6 \mathrm{~kg}$ of milk per calf and day is available. Milk yield controls were performed on the last day before moving to the experiment and then weekly thereafter. The US group was housed in a pen of $9 \times 4.5 \mathrm{~m}$ 
(3 nursing cows and 10-12 heifer calves). Calves were not housed individually with a foster cow. Cows were tied in a pen, and calves were kept loose.

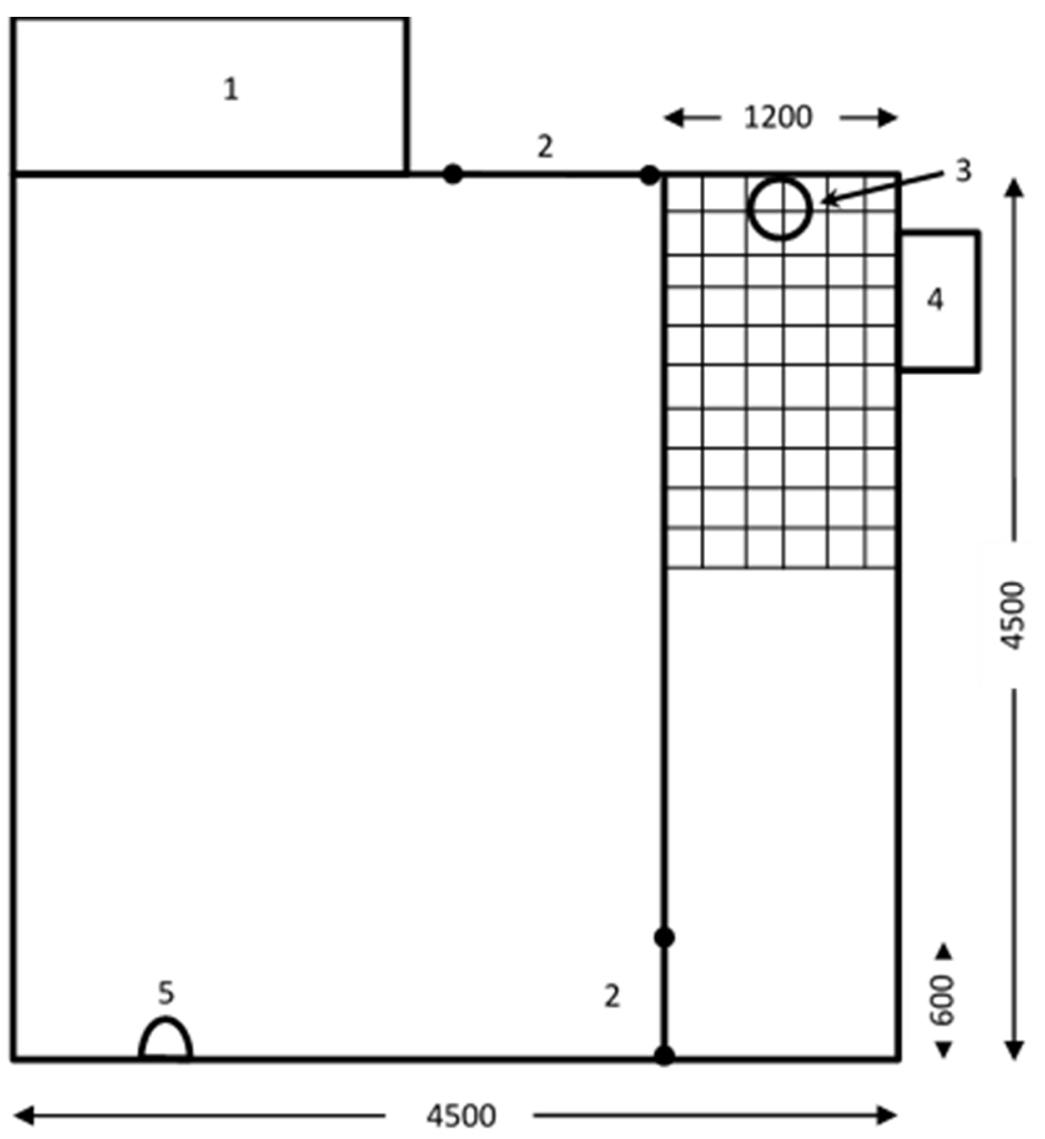

Figure 1. Individual pen for the calf and the mother of the RS group. 1-Concrete feed trough for cow; 2-gate; 3 - starter mixture feeder; 4 -hanging hay feeder; 5 -cow drinker.

After having nursed their dams in an individual pen for $24 \mathrm{~h}$, the calves in the conventional rearing group $(\mathrm{CR}, n=17)$ were kept individually in hutches from 2 nd to 56 th day (bucket with nipple, MR; 2 nd day, $3 \times 0.5 \mathrm{~kg}$; 3 rd day, $3 \times 1.0 \mathrm{~kg}$; 4 th day, $3 \times 1.5 \mathrm{~kg}$; and from 5th day $6 \mathrm{~kg} /$ day to 21 st day $3 \times$ daily) and then in a loose housing pen from the 57 th day (bucket with nipple, MR, $6 \mathrm{~kg} /$ day, $2 \times$ daily) to weaning. The hutches were made from fibre-glass, used from the second day of life to relocation to group housing at the age of 8 weeks. Each hutch $(1.8 \times 1.2 \mathrm{~m})$ had an outside fenced yard of $1.8 \times 1.2 \mathrm{~m}$, bedded with straw. The hutches were arranged in rows, $0.8 \mathrm{~m}$ apart. The heifers could see and touch each other through the openings in the upper part of the pen wall or fenced yard of the hutch.

The calves could eat a starter mixture (SM) and alfalfa hay as a free choice until weaning. The RS and US calves could eat SM and alfalfa hay from a special feeder as a free choice, and the calves had no access to fodder the cows from the trough. Cows could not eat from the calves' feeder (Figure 1). CR group calves received SM from a bucket and alfalfa hay from a crib feeder. All calves were offered the same SM and forage.

The MR with dry matter (DM), 94.7\%, was composed of dry whey, dry buttermilk, dry skimmed milk, animal fat, whey dried with vegetable oil, and wheat gluten (crude protein $226 \mathrm{~g} / \mathrm{kg} \mathrm{DM}$, crude fat $196 \mathrm{~g} / \mathrm{kg} \mathrm{DM}$, ash $87 \mathrm{~g} / \mathrm{kg}$ DM, and crude fibre $6.0 \mathrm{~g} / \mathrm{kg}$ DM). The SM (DM 89.3\%) contained barley, wheat, soybean meal, oats, corn, and a mineral mixture (crude protein $214 \mathrm{~g} / \mathrm{kg}$ DM, crude fat $32 \mathrm{~g} / \mathrm{kg} \mathrm{DM}$, and ash $81 \mathrm{~g} / \mathrm{kg} \mathrm{DM}$ ).

The heifers were also divided (not random) according to the season of the birth (SB1 = January-March, $N=21$; SB2 = April-June, $N=14$; SB3 = July-September, $N=7$; 
and SB4 = October-December, $N=9$ ). The division into rearing groups was as follows: RS $(\mathrm{SB} 1=9, \mathrm{SB} 2=3, \mathrm{SB} 3=3$, and SB4 = 3; 18), $\mathrm{US}(\mathrm{SB} 1=5, \mathrm{SB} 2=3, \mathrm{SB} 3=4$, and SB4 = 4; $16), C R(S B 1=7, S B 2=7, S B 3=1$, and $S B 4=2 ; 17)$. The seasonal averages of the mean temperature, minimum temperature, and maximum temperature measured on the research farm were as follows: SB1 $\left(1.5^{\circ} \mathrm{C},-2.3^{\circ} \mathrm{C}\right.$, and $\left.5.5^{\circ} \mathrm{C}\right)$, SB2 $\left(13.9^{\circ} \mathrm{C}, 8.1^{\circ} \mathrm{C}\right.$, and $\left.20.0^{\circ} \mathrm{C}\right)$, SB3 $\left(17.7^{\circ} \mathrm{C}, 12.6{ }^{\circ} \mathrm{C}\right.$, and $\left.24.2^{\circ} \mathrm{C}\right)$, and SB4 $\left(4.6{ }^{\circ} \mathrm{C}, 1.2^{\circ} \mathrm{C}\right.$, and $\left.8.4{ }^{\circ} \mathrm{C}\right)$.

The experimental heifers originated from four fathers $(\mathrm{F} 1=7, \mathrm{~F} 2=14, \mathrm{~F} 3=21$, and $\mathrm{F} 4=9$ ). The distribution (not random) was as follows: $\mathrm{RS}(\mathrm{F} 1=4, \mathrm{~F} 2=3, \mathrm{~F} 3=6$, and F4 = 5; 18), $\mathrm{US}(\mathrm{F} 1=1, \mathrm{~F} 2=7, \mathrm{~F} 3=7$, and $\mathrm{F} 4=1 ; 16)$, and $\mathrm{CR}(\mathrm{F} 1=2, \mathrm{~F} 2=4, \mathrm{~F} 3=8$, and $\mathrm{F} 4=3 ; 17)$.

All animals were weaned abruptly at the age of 12 weeks and moved to a group housing pen, where equal conditions of nutrition were ensured. Each treatment group had its own pens, and the pens were differentiated by age, so that the age difference in one pen was not higher than 21 days. Approximately 10-15 calves were kept in a pen of $9 \times 4.5 \mathrm{~m}$. Each heifer had free access to clean drinking water in a plastic bucket or an automatic drinker throughout the study.

After weaning from milk feeding, all heifers were kept separately in age-balanced groups in loose housing bedded pens with the same ration.

\subsection{Diet Management after Weaning}

The heifers received $1.5 \mathrm{~kg}$ of SM per day and alfalfa hay was offered as a free choice from weaning to 180 days. From the age of 90 days, they were also fed corn silage.

The composition of alfalfa hay (DM 88.8\%) was crude protein $212 \mathrm{~g} / \mathrm{kg}$ DM, total digestible nutrients $595 \mathrm{~g} / \mathrm{kg}$ DM, acid detergent fibre $294 \mathrm{~g} / \mathrm{kg}$ DM, neutral detergent fibre $351 \mathrm{~g} / \mathrm{kg}$ DM, Ca $13.8 \mathrm{~g} / \mathrm{kg}$ DM, and P $2.6 \mathrm{~g} / \mathrm{kg}$ DM. Corn silage ingredients (DM $43.21 \%$, pH 4.06) represented $68.6 \mathrm{~g} / \mathrm{kg}$ DM of crude protein, $406 \mathrm{~g} / \mathrm{kg}$ DM of starch, $518 \mathrm{~g} / \mathrm{kg}$ DM of non-fibrous carbohydrates, $12.0 \mathrm{~g} / \mathrm{kg}$ DM of sugar, $33.4 \mathrm{~g} / \mathrm{kg}$ DM of crude fat, $232.8 \mathrm{~g} / \mathrm{kg}$ DM of acid detergent fibre, $345.1 \mathrm{~g} / \mathrm{kg}$ DM of neutral detergent fibre, $51.8 \mathrm{~g} / \mathrm{kg}$ DM of ash, $2.2 \mathrm{~g} / \mathrm{kg}$ DM of Ca, $2.3 \mathrm{~g} / \mathrm{kg}$ DM of $\mathrm{P}, 1.5 \mathrm{~g} / \mathrm{kg} \mathrm{DM}$ of $\mathrm{Mg}, 9.3 \mathrm{~g} / \mathrm{kg}$ $\mathrm{DM}$ of $\mathrm{K}$, and $1.3 \mathrm{~g} / \mathrm{kg} \mathrm{DM}$ of $\mathrm{S}$.

From the 181st to 360th days, all heifers were fed the same total mixed feed ration (TMR). The concentrate mixture (CM) $(1.5 \mathrm{~kg} /$ day, DM 90.1\%) was fed separately; it contained sunflower cake, cotton seed cake, corn, wheat bran, mineral mixture, salt (crude protein $183 \mathrm{~g} / \mathrm{kg}$ DM, crude fat $35 \mathrm{~g} / \mathrm{kg}$ DM, and ash $92 \mathrm{~g} / \mathrm{kg} \mathrm{DM}$ ). The TMR consisted of corn silage, alfalfa haylage, alfalfa hay, barley straw, sugar-beet pulp, brewer's grain, and mineral/vitamins supplements.

From the 361st to 450th days, the heifers were fed a TMR consisting of corn silage, alfalfa haylage, alfalfa hay, barley straw, brewer's grain, sugarbeet pulp, and CM. The feed ration contained $6.7 \mathrm{~kg} \mathrm{DM}, 64.4 \mathrm{MJ}$ net energy content for lactation (NEL), $0.52 \mathrm{~kg}$ protein digestible in the small intestine (PDI), and $1.98 \mathrm{~kg}$ of crude protein.

The heifers were fed a TMR consisting of corn silage, alfalfa haylage, alfalfa hay, barley straw, brewer's grain, sugarbeet pulp, and CM from the 451st to 570th days throughout the study. The feed ration contained $8.3 \mathrm{~kg}$ DM, $78.3 \mathrm{MJ}$ NEL, $0.57 \mathrm{~kg}$ PDI, and $2.62 \mathrm{~kg}$ of crude protein [44].

Feeding was allowed throughout the $24 \mathrm{~h}$ period. Automatic watering troughs were located next to the feed bunks. The total mixed ration was calculated according to Slovakian nutrient requirements of dairy cattle [44]. Equal conditions of nutrition were ensured in all groups.

\subsection{Live Body Weight Growth}

Live body weight (LBW) of the heifer calves was recorded each month, from 360 to 570 days. The average daily gain (ADG) was calculated as the average change in live body weight during a specified period. The heifers were weighed on the mobile livestock scale (DVM, Soehnle, Germany), load capacity up to $2000 \mathrm{~kg}$, weighing accuracy $\pm 0.2 \mathrm{~kg}$. 


\subsection{Health and Reproduction}

All animals included in the experiment were appropriately vaccinated and disease tested. Diseases that were managed by law are bovine Tuberculosis and Leptospirosis. The methods of the authors of [45-48] for the daily health evaluation (diarrhoea, respiratory condition, mastitis, clinical laminitis, and injuries) were used. The loss of a foetus was diagnosed when a foetus dies between 43 and 151 days of pregnancy.

The breeding program of heifers began at 13 months of age, limiting live body weight for a breeding age was $360 \mathrm{~kg}$. Heifers were moved into the artificial insemination (AI) breeding pen as they reached the height and weight targets and were ready for breeding. The heifers were bred by AI with frozen-thawed semen. The hormonal breeding programs were not used.

The heat detection was checked twice a day by a combination of visual observation of behavioural signs of oestrus and tail-paint removal. The primary sign of heat was standing to be mounted by a herd mate. The secondary signs include ruffled tail head hair, clear mucus discharge, increased activity, mounting other heifers, and chin resting. The heifers were inseminated 6 to $12 \mathrm{~h}$ after observation of behavioural oestrus (performed inseminations twice a day). If a heifer was observed in heat in the morning, we inseminated her in the afternoon. If a heifer was observed in heat in the afternoon, we bred her the next morning. Once-a-day breeding was also used if a heifer was bred in the morning. Re-inseminations at detected oestrus occurred any time after a previous insemination.

Confirmation of pregnancy was performed by transrectal palpation 45 to 60 days after insemination. All inseminations and pregnancy diagnoses were performed by the same operator. For the measure of fertility (reproductive successes) in heifers, we used a number of services per conception (NSC), also referred to as an insemination index. The second parameter was the percentage of conception after the first insemination (PCFI), also referred to as the conception rate to first inseminations.

The NSC represents the mean number of artificial inseminations performed in order to obtain a pregnancy. It was calculated by dividing the total number of breeding for pregnant heifers in the group by the number of pregnant heifers.

The PCFI was calculated as the number of heifers conceiving at the first insemination expressed as a percentage of the total number of heifers or as the proportion of inseminations or services that result in conception [48-50]. The conception rate is then the number of conceptions that resulted in a successful pregnancy expressed as a percentage of the total number of inseminations for those cows $[48,50,51]$.

To determine this values, dates of every insemination were collected and documented. The date of conception for each pregnant heifer was also recorded, based on pregnancy diagnoses.

\subsection{Statistical Calculations}

The data were analysed by the statistical package STATISTIX, Version 10.0. (Analytical Software, PO Box 12185, Tallahassee, FL, USA). The dependent variables were LBW, ADG, and reproductive and labyrinth parameters. The independent variables were the treatment group (T), season of birth (S), and father's lineage (F). The effects of observed factors (treatment, season of birth, and father's lineage) were evaluated using the General linear model ANOVA (three-factorial with interactions) with all effects considered a fixed effect (treatment) or random effects (season of birth and father's lineage) and with an error term as a random effect distributed by the model equation. We used the classical distribution $p$ values to express the statistical significance: ${ }^{*} p<0.05,{ }^{* *} p<0.01$, and ${ }^{* * *} p<0.001$. If the $p$ value was in the range of 0.05 to 0.1 , we evaluated it as a tendency.

The normality of data distribution was evaluated by the Wilk-Shapiro/Rankin Plot procedure (Analytical Software, PO Box 12185, Tallahassee, FL, USA). All of the parameters were normally distributed, and no relevant outliers appeared. The homogeneity of variance of the observed variables in groups was calculated by preliminary variance tests, which determined whether the variabilities were equal. The Bartlett's test for the equality of 
variance tests was used for an unequal size of samples. Differences among groups were tested by Comparisons of Mean Ranks. Significant differences among means were tested by Bonferroni's test. All values were reported as means \pm standard error of the mean (SE). The interactions between observed factors (treatment, season of birth, and father's lineage) were also computed.

The following model of General AOV/AOCV on observed factors (treatment, season of the birth, and father) was used:

$$
Y i j k=\mu+T i+S j+F k+\alpha i j+\beta i k+\gamma j k+\varepsilon i j k
$$

where Yijk is a dependent variable, $\mu$ is the overall mean, $T i$ is the effect of factor treatment on the level $i, S j$ is the effect of factor season of birth on the level $j, F k$ is the effect of factor father's lineage on the level $k$, $\alpha i j$ is the interaction between factor $T$ on the level $i$ and factor $S$ on the level $j, \beta i k$ is the interaction between factor $T$ on the level $i$ and factor $F$ on the level $k, \gamma j k$ is the interaction between factor $S$ on the level $j$ and factor $F$ on the level $k$, and $\varepsilon i j k$ is the residual error.

\section{Results}

\subsection{Growth}

\subsubsection{Factor Treatment Rearing (T)}

On the 360th day, the LBW was inconclusively the highest in the US group (RS $344.45 \pm 9.38 \mathrm{~kg}$, US $355.24 \pm 10.83 \mathrm{~kg}$, and CR $332.98 \pm 10.11 \mathrm{~kg}$; $p=0.4021$ ). The course of more intensive growth of the US group was maintained until the end of monitoring (Figure 2). On the contrary, the lowest growth of the LBW in the period from the 360th to the 570th day was found in the CR group. A statistical difference among groups was found on the 450th day (RS $420.94 \pm 8.25 \mathrm{~kg}$, US $439.24 \pm 9.53 \mathrm{~kg}$, and CR $406.46 \pm 8.89 \mathrm{~kg}$; $p=0.0333$, US: $\left.\mathrm{CR}^{*}\right)$. At the end of the trial (570 day), no significantly highest LBW was recorded in the US group, with the lowest one found in CR (RS $531.37 \pm 9.13 \mathrm{~kg}$, US $542.28 \pm 10.55 \mathrm{~kg}$, and CR $519.58 \pm 9.84 \mathrm{~kg} ; p=0.2420$ ) (Figure 2). The ADG from the 360th to 570th days were not different (RS $0.89 \pm 0.04 \mathrm{~kg}$, US $0.89 \pm 0.04 \mathrm{~kg}$, and CR $0.88 \pm 0.04 \mathrm{~kg} ; p=0.9992)$.

600

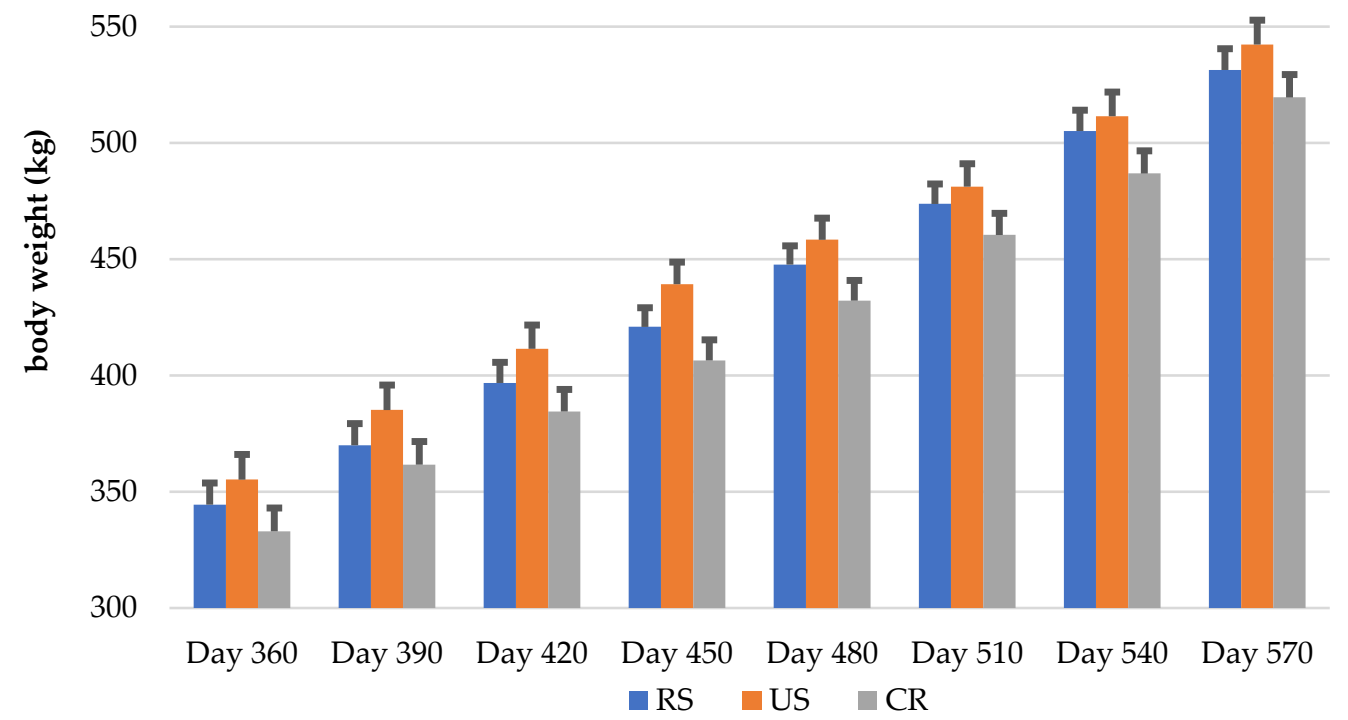

Figure 2. Growth of the live body weight of heifers (kg). 


\subsubsection{Season of Birth and Father's Lineage Factors (SB and F)}

When evaluating the effect of the season of birth on LBW, significant differences were recorded only at the age of 360 days (SB1 $329.19 \pm 9.06 \mathrm{~kg}$, SB2 $368.11 \pm 10.48 \mathrm{~kg}$, SB3 $364.49 \pm 14.17 \mathrm{~kg}$, and SB4 $\left.315.10 \pm 12.85 \mathrm{~kg} ; p=0.0031, \mathrm{SB} 2: \mathrm{SB} 1, \mathrm{SB} 4{ }^{*}\right)$. Throughout the experiment, heifers of SB2 had the highest LBW, heifers of SB4 weighed the least up to 510 days of age, and heifers of SB3 weighed the least up between 540 and 570 days of age (Table 1).

Table 1. Effects of birth season on the heifer's live body growth $(\mathrm{kg})$.

\begin{tabular}{|c|c|c|c|c|c|c|c|}
\hline Group & $\mathbf{N}$ & Mean & SE & $\begin{array}{c}p \text { Value/ } \\
\text { Significance }\end{array}$ & Mean & SE & $\begin{array}{c}p \text { Value/ } \\
\text { Significance }\end{array}$ \\
\hline & & \multicolumn{3}{|c|}{ Day 360} & \multicolumn{3}{|c|}{ Day 390} \\
\hline SB1 & 21 & 329.2 & 9.1 & $0.0031^{* *}$ & 366.5 & 6.9 & 0.1958 \\
\hline SB2 & 8 & 368.1 & 10.5 & SB2: SB1, SB4 * & 383.0 & 20.3 & \\
\hline SB3 & 5 & 364.5 & 14.2 & & 387.4 & 16.2 & \\
\hline \multirow[t]{2}{*}{ SB4 } & 8 & 315.1 & 12.8 & & 355.9 & 9.2 & \\
\hline & & \multicolumn{3}{|c|}{ Day 420} & \multicolumn{3}{|c|}{ Day 450} \\
\hline SB1 & 21 & 394.1 & 6.4 & 0.1224 & 420.9 & 6.2 & 0.0772 \\
\hline SB2 & 8 & 412.5 & 20.6 & & 438.7 & 19.0 & \\
\hline SB3 & 5 & 405.6 & 14.8 & & 424.4 & 14.7 & \\
\hline \multirow[t]{2}{*}{ SB4 } & 8 & 383.6 & 8.6 & & 408.1 & 8.1 & \\
\hline & & \multicolumn{3}{|c|}{ Dav 480} & \multicolumn{3}{|c|}{ Day 510} \\
\hline SB1 & 21 & 449.3 & 6.5 & 0.1075 & 474.6 & 6.6 & 0.3547 \\
\hline SB2 & 8 & 461.0 & 17.0 & & 482.4 & 15.9 & \\
\hline SB3 & 5 & 446.0 & 13.1 & & 474.4 & 12.9 & \\
\hline \multirow[t]{2}{*}{ SB4 } & 8 & 431.9 & 7.4 & & 461.7 & 10.9 & \\
\hline & & \multicolumn{3}{|c|}{ Day 540} & \multicolumn{3}{|c|}{ Day 570} \\
\hline SB1 & 21 & 508.6 & 7.9 & 0.3982 & 535.0 & 7.9 & 0.6746 \\
\hline SB2 & 8 & 507.4 & 13.8 & & 534.2 & 12.9 & \\
\hline SB3 & 5 & 497.8 & 14.6 & & 528.8 & 16.4 & \\
\hline SB4 & 8 & 497.7 & 13.1 & & 533.1 & 14.2 & \\
\hline
\end{tabular}

${ }^{*} p<0.05 ;{ }^{* *} p<0.01 ;$ SE = standard error of the mean; SB1 = born January-March, SB12 = born April-June, SB3 = born July-September, SB4 = born October-December.

The ADGs were highest in the SB1 group from the 360th day to the 480th day, followed by SB4. The lowest values were mostly observed in the SB3 group. Significant differences were recorded between 390 and420 days (SB1 $0.95 \pm 0.06 \mathrm{~kg}$, SB2 $0.94 \pm 0.07 \mathrm{~kg}$, SB3 $0.62 \pm 0.10 \mathrm{~kg}$, and SB4 $0.86 \pm 0.09 \mathrm{~kg} ; p=0.0440, \mathrm{SB} 1:$ SB3 $\left.{ }^{*}\right)$ and between 540 and 570 days (SB1 $0.89 \pm 0.06 \mathrm{~kg}$, SB2 $0.87 \pm 0.07 \mathrm{~kg}$, SB3 $1.04 \pm 0.09 \mathrm{~kg}$, and SB4 $1.18 \pm 0.09 \mathrm{~kg}$; $p=0.0245, \mathrm{SB} 2$ : SB4 *). The ADG for the whole period, from the 360th to the 570th days, differed significantly (SB1 $0.98 \pm 0.04 \mathrm{~kg}$, SB2 $0.81 \pm 0.04 \mathrm{~kg}$, SB3 $0.73 \pm 0.06 \mathrm{~kg}$, and SB4 $1.03 \pm 0.05 \mathrm{~kg} ; p=0.0002$, SB3: SB1, SB4 **, SB2: SB1, SB4 *) (Table 2). Significant interactions between the rearing group and the season of birth were calculated in the ADG 360 to 390 days $\left(p=0.0285^{*}\right)$ and in the ADG for the entire experiment $\left(p=0.0499^{*}\right)$.

No significant differences were found in the father's lineage effect on the growth.

\subsection{Health and Reproduction}

Two heifers were culled from the RS group, one at 18 months of age due to infections causing a respiratory problem (pneumonia) and the other for an injury (limb fracture) at 19 months of age. One heifer of the CR group had to be culled due to foetal loss (122 days of pregnancy) at the age of 19 months.

The ages of the first insemination service (RS $427.3 \pm 3.9$ days, $N=18$; US $412.7 \pm$ 5.3 days, $N=16$; $\mathrm{CR} 448.2 \pm 4.7$ days, $N=17 ; p=0.0386$, $\mathrm{US}: \mathrm{CR}^{*}$ ) and the conception (RS $452.1 \pm 5.9$ days, $N=18$; US $441.3 \pm 8.8$ days, $N=16$; CR $472.4 \pm 7.3$ days; $N=17$; $p=0.0420 *$ US: $\mathrm{CR}^{*}$ ) were different. The LBW at the first insemination service and at the conception were as follows: RS $402.4 \pm 6.9 \mathrm{~kg}, N=18$; US $405.3 \pm 7.9 \mathrm{~kg}, N=16$; 
CR $405.5 \pm 9.2 \mathrm{~kg}, N=17 ; p=0.8324 ;$ RS $422.7 \pm 11.2 \mathrm{~kg}, N=18 ;$ US $433.1 \pm 9.2 \mathrm{~kg}, N=16 ;$ $\mathrm{CR} 426.4 \pm 10.7 \mathrm{~kg}, N=17 ; p=0.6369$.

Table 2. Effects of birth season on the average daily gains in heifers $(\mathrm{kg})$.

\begin{tabular}{|c|c|c|c|c|c|c|c|}
\hline Group & $\mathbf{N}$ & Mean & SE & $\begin{array}{c}p \text { Value/ } \\
\text { Significance }\end{array}$ & Mean & SE & $\begin{array}{c}p \text { Value/ } \\
\text { Significance }\end{array}$ \\
\hline & & \multicolumn{3}{|c|}{ From the 360th day to the 390th day } & \multicolumn{3}{|c|}{ From the 390th day to the 420 th day } \\
\hline SB1 & 21 & 1.26 & 0.22 & 0.1250 & 0.95 & 0.06 & $0.0440 *$ \\
\hline SB2 & 8 & 0.30 & 0.36 & & 0.94 & 0.07 & SB1:SB3* \\
\hline SB3 & 5 & 0.16 & 0.34 & & 0.62 & 0.10 & \\
\hline \multirow[t]{2}{*}{ SB4 } & 8 & 1.48 & 0.40 & & 0.86 & 0.09 & \\
\hline & & \multicolumn{3}{|c|}{ From the 420th day to the 450th day } & \multicolumn{3}{|c|}{ From the 450th day to the 480th day } \\
\hline SB1 & 21 & 0.89 & 0.08 & 0.3774 & 0.94 & 0.06 & 0.1528 \\
\hline SB2 & 8 & 0.87 & 0.10 & & 0.74 & 0.11 & \\
\hline SB3 & 5 & 0.63 & 0.05 & & 0.72 & 0.08 & \\
\hline \multirow[t]{2}{*}{ SB4 } & 8 & 0.82 & 0.12 & & 0.79 & 0.06 & \\
\hline & & \multicolumn{3}{|c|}{ From the 480 th day to the 510th day } & \multicolumn{3}{|c|}{ From the 510th day to the 540th day } \\
\hline SB1 & 21 & 0.84 & 0.04 & 0.1177 & 1.13 & 0.13 & 0.1934 \\
\hline SB2 & 8 & 0.71 & 0.07 & & 0.83 & 0.09 & \\
\hline SB3 & 5 & 0.94 & 0.08 & & 0.78 & 0.07 & \\
\hline \multirow[t]{2}{*}{ SB4 } & 8 & 0.99 & 0.15 & & 1.20 & 0.10 & \\
\hline & & \multicolumn{3}{|c|}{ From the 540th day to the 570th day } & \multicolumn{3}{|c|}{ From the 360th day to the 570th day } \\
\hline SB1 & 21 & 0.89 & 0.06 & $0.0245 *$ & 0.98 & 0.04 & $0.0002 * * *$ \\
\hline SB2 & 8 & 0.87 & 0.07 & SB2:SB4* & 0.81 & 0.04 & SB2:SB1,SB4* \\
\hline SB3 & 5 & 1.04 & 0.09 & & 0.73 & 0.06 & SB3: SB1,SB4 ** \\
\hline SB4 & 8 & 1.18 & 0.09 & & 1.03 & 0.05 & \\
\hline
\end{tabular}

The percentages of conception after the first insemination were RS $66.66 \%, N=18$; US $56.25 \%, N=16$; CR $58.82 \%, N=17$, and the numbers of services per conception (insemination indexes) (RS $1.39 \pm 0.15, N=18$; US $1.51 \pm 0.17, N=16$; CR $1.43 \pm 0.16$; $N=17 ; p=0.8790$ ) did not differ statistically (Table 3 ). These reproductive indicators were not statistically different in comparison with the season of birth or father's lineages.

Table 3. Effect of treatment rearing on the reproduction parameters of heifers.

\begin{tabular}{|c|c|c|c|c|}
\hline Group & $\mathbf{N}$ & Mean & SE & $\begin{array}{c}p \text { Value/ } \\
\text { Significance }\end{array}$ \\
\hline \multicolumn{5}{|c|}{ Age of the first insemination (days) } \\
\hline RS & 18 & 427.3 & 3.9 & $0.0386 *$ \\
\hline US & 16 & 412.7 & 5.3 & US:CR * \\
\hline CR & 17 & 448.2 & 4.7 & \\
\hline \multicolumn{5}{|c|}{ Live body weight at the first insemination $(\mathrm{kg})$} \\
\hline RS & 18 & 402.4 & 6.9 & 0.8324 \\
\hline US & 16 & 405.3 & 7.9 & \\
\hline CR & 17 & 405.5 & 9.2 & \\
\hline \multicolumn{5}{|c|}{ Age of the conception (days) } \\
\hline RS & 18 & 452.1 & 5.9 & $0.0420 *$ \\
\hline US & 16 & 441.3 & 8.8 & US:CR * \\
\hline $\mathrm{CR}$ & 17 & 472.4 & 7.3 & \\
\hline \multicolumn{5}{|c|}{ Live body weight at the conception $(\mathrm{kg})$} \\
\hline RS & 18 & 422.7 & 11.2 & 0.6369 \\
\hline US & 16 & 433.1 & 9.2 & \\
\hline $\mathrm{CR}$ & 17 & 426.4 & 10.7 & \\
\hline \multicolumn{5}{|c|}{ Number of services per conception } \\
\hline RS & 18 & $1.39^{1}$ & 0.15 & 0.8790 \\
\hline US & 16 & 1.51 & 0.17 & \\
\hline CR & 17 & 1.43 & 0.16 & \\
\hline
\end{tabular}

* $p<0.05 ; \mathrm{RS}=$ restrictive suckling group; US = multiple suckling group; CR = conventional reared group $\mathrm{SE}=$ standard error of the mean. 


\section{Discussion}

\subsection{Growth}

\subsubsection{Factor Treatment Rearing (T)}

In the present study, the LBW differences were mostly not significant. The LBW growth was the highest in the US group, while the lowest growth of the LBW was in the CR group. This was actually a continuation of the previous experiment course [42], when the highest live weight at weaning from milk-liquid nutrition in the US group was recorded. Additionally, the trend of the highest LBW of the US group was shown from the beginning of the present experiment on the 360th day until the 570th day. Please note that these former results support our findings that the increased LBW in US heifers kept with foster cows was a result of greater milk intake to weaning. Additionally, suckling of several calves empties the foster cow udder properly and can increase milk creation. This finding is consistent with previous studies [52-55].

High amounts milk consumption improve the later efficiency of heifers [19,21]. We must also consider the faster adaptation of calves to crude feed and that the loose housing of calves was associated with an increased appetite [56-58]. In our opinion, the higher growth in US heifers was caused by the better liquid nutrition compared with the CR group $[2,59,60]$.

There was a higher LBW in the RS group compared with the CR group. Our results are consistent with other findings $[9,14,61]$ that the growth of suckling calves (RS) are higher than those artificially reared (CR), which probably received less valuable liquid nutrition $[5,6,12,62-64]$.

There was also a lower LBW at $570 \mathrm{~d}$ in the CR group compared with groups US and RS (519.6 kg against $542.3 \mathrm{~kg}$ and $531.4 \mathrm{~kg}$ ). The compensatory growth of the CR group was found, but this was not sufficient. It can be seen from almost the same absolute weight gain from the 360th to the 570th days. The CR group had a major initial disadvantage.

\subsubsection{Season of Birth and Father's Lineage Factors (SB, F)}

We hypothesised that the season of birth may play an important role in growth and behaviour. The highest LBW was observed in SB2 heifers and SB4 heifers, while SB3 heifers weighed the least up to 570 days of age. The ADGs were significantly highest in the SB1 and SB4 groups. The close relationship of LBW growth to seasonal effects is also evidenced by significant interactions between the group and the season.

The significant and persistently greater LBW in the heifers that were not stressed compared with those affected by heat may be explained with the help of additional factors. In farm conditions, they can suffer from stress during several phases of the reproduction, but calves can be significantly affected also by prenatal stress during the mid or late gestation of their mothers $[26,27,65]$. The effect of prenatal exposure to high temperatures is generally considered the worst. High temperatures at the end of pregnancy generate metabolic changes [41,65-67].

The last trimester of gestation is a critical period for foetal growth and physiological transition into the next period of life. Maternal nutrition during pregnancy on the calf remain of practical significance to livestock producers [32]. Calves born to cows under heat stress during the dry period are lighter at birth and have lower postnatal growth and passive immunity than calves born to cooled cows $[28,38,39,41,68-71]$. These seasonal differences are likely caused by seasonal metabolic adaptations to enhance survival of the calf in different circumstances [64,66,67,72].

Although heat stress during late gestation is accepted to affect neonate calf foetus [33], this effect is expected to be less significant in the moderate Slovakian climate [69,72]. In the present study, pregnant mothers were intensively managed and a balanced ration was fed. The limited influence of the season on nutritional status was expected. It is possible that seasons combine the effect of the photoperiod, temperature, and nutritional status. Multiple hypotheses have been suggested, but the exact underlying mechanism of these effects remains unclear [28]. 
In the present study, maternal heat stress during late gestation decreases BW by up to 570 days of age in SB3 group heifers born between July and September. These results corroborated those of other authors $[68,69,72-77]$ and confirm that a calf body weight can be significantly impacted by heat stress during the final weeks of gestation. However, what about the SB4 group? The negative results of heat stress often appear with a delay, and a carry-over effect may be experienced. The summer heat stress may affect the cows until autumn $[27,29]$.

\subsection{Health and Reproduction}

Although the authors of [33,47-51,78-82] stated that the artificial rearing of calves presents a combination of emotional and nutritional stresses that reduces their immune response and health condition, the incidence of health problems was very low in all treatment groups, and there were no differences in the occurrence of illnesses in the study.

In the present study, differences between groups were calculated only at the first insemination and the beginning of pregnancy. It has always been closely related to LBW, as described by the authors [31,83-85].

The group with the highest LBW (US) was inseminated and fertilised first, and heifers of CR group with the lowest LBW growth were inseminated and fertilised last. There were no significant differences in LBW between the groups during first insemination or fertilisation. Similarly, no significant differences were found in PCFI and NSC. Additionally, no significant differences were calculated in the evaluation of the factors season of birth and father's origin. Studies [26,41] showed that heifers born to heat stressed dry cows have a greater number of services per conception. At the present work, no effect of the exposition of mothers of the SB3 group heifers to heat stress during late gestation was observed on age at $\mathrm{AI}$ and on age of first parturition of daughters.

\section{Conclusions}

This study was conducted to determine whether factors of rearing, season of the birth, and father lineage have an effect on the growth and reproduction of dairy heifers from the 360 th to the 570 th days.

The live body weight was the highest in the heifers reared in housing with foster cows (US), and the lowest weights were recorded in the heifers reared in hutches (CR). This was also evident at the first insemination service and at the conception, which were the highest in the CR group. The growth was influenced also by the season of birth; the highest growth of live body was found in SB2 heifers.

The results indicate that the method used to rear heifers and the season of birth may have a significant impact on their later growth in puberty and first pregnancy.

Author Contributions: M.U., behavioural and computer specialist, J.B., senior scientist of animal hygiene, A.H., technical specialist, and P.K., behavioural specialist. They are all from the Research Institute of Animal Production Nitra-National Agricultural and Food Centre, Slovakia. Each author participated sufficiently in the study. M.U. and J.B. conceived and designed the experiments; A.H. and P.K. performed the experiments; Jan Broucek analysed the data; M.U. and J.B. wrote the manuscript. All authors have read and agreed to the proposed version of the manuscript.

Funding: This research received no external funding.

Institutional Review Board Statement: Not applicable.

Informed Consent Statement: Not applicable.

Data Availability Statement: The data are available upon reasonable request by correspondence with the author.

Acknowledgments: This article was written based on data project Sustainable Smart Farming Systems 313011W112, supported by the Operational Programme Integrated Infrastructure and the European Regional Development Fund, and APVV-18-0121 of the SRDA, Slovakia.

Conflicts of Interest: The authors declare no conflict of interest. 


\section{References}

1. Albright, J.L.; Arave, C.W. The Behaviour of Cattle; CAB International: Wallingford, UK, 1997; p. 306.

2. Flower, F.C.; Weary, D.M. The effects of early separation on the dairy cow and calf. Anim. Welf. 2003, 12, 339-348. [CrossRef]

3. Jasper, J.; Weary, D.M. Effects of ad libitum milk intake on dairy calves. J. Dairy Sci. 2002, 85, 3054-3058. [CrossRef]

4. Wagenaar, J.P.T.M.; Langhout, J. Practical implications of increasing 'natural living' through suckling systems in organic dairy calf rearing. NJAS Wagening. J. Life Sci. 2007, 54, 375-386. [CrossRef]

5. Khattak, A.H.K.; Wasay, A.; Ali, T.; Iqbal, M.; Kalim, K.; Hassan, M.F.; Mobashar, M.; Ahmad, N.; Iqbal, A.; Islam, M.N. Influence of different weaning ages on growth performance of achai crossed jersey calves. Pak. J. Zool. 2018, 50, 2159-2163. [CrossRef]

6. Meagher, R.K.; Beaver, A.; Weary, D.M.; Von Keyserlingk, M.A.G. A systematic review of the effects of prolonged cow-calf contact on behavior, welfare, and productivity. J. Dairy Sci. 2019, 102, 5765-5783. [CrossRef]

7. Loberg, J.; Lidfors, L. Effect of stage of lactation and breed on dairy cows acceptance of foster calves. Appl. Anim. Behav. Sci. 2001, 74, 97-108. [CrossRef]

8. $\quad$ Loberg, J.M.; Hernandez, C.E.; Thierfelder, T.; Jensen, M.B.; Berg, C.; Lidfors, L. Weaning and separation in two steps-A way to decrease stress in dairy calves suckled by foster cows. Appl. Anim. Behav. Sci. 2008, 111, 222-234. [CrossRef]

9. Krohn, C.C. Effects of different suckling systems on milk production, udder health, reproduction, calf growth and some behavioural aspects in high producing dairy cows-A review. Appl. Anim. Behav. Sci. 2001, 72, 271-280. [CrossRef]

10. Johnsen, J.F.; Zipp, K.A.; Kalber, T.; de Passille, A.M.; Knierim, U.; Barth, K.; Mejdell, C.M. Is rearing calves with the dam a feasible option for dairy farms?-Current and future research. Appl. Anim. Behav. Sci. 2016, 181, 1-11. [CrossRef]

11. De Passillé, A.M.; Marnet, P.G.; Lapierre, H.; Rushen, J. Effects of twice-daily nursing on milk ejection and milk yield during nursing and milking in dairy cows. J. Dairy Sci. 2008, 91, 1416-1422. [CrossRef]

12. Roth, B.A.; Barth, K.; Gygax, L.; Hillmann, E. Influence of artificial vs. mother-bonded rearing on sucking behaviour, health and weight gain in calves. Appl. Anim. Behav. Sci. 2009, 119, 143-150. [CrossRef]

13. Fröberg, S.; Gratte, E.; Svennersten-Sjaunja, K.; Olsson, I.; Berg, C.; Orihuela, A.; Galina, C.S.; Garcia, B.; Lidfors, L. Effect of suckling ('restricted suckling') on dairy cows' udder health and milk let-down and their calves' weight gain, feed intake and behaviour. Appl. Anim. Behav. Sci. 2008, 113, 1-14. [CrossRef]

14. Johnsen, J.F.; de Passillé, A.M.; Mejdell, C.M.; Boe, K.E.; Grondahl, A.M.; Beaver, A.; Rushen, J.; Weary, D.M. The effect of nursing on the cow-calf bond. Appl. Anim. Behav. Sci. 2015, 163, 50-57. [CrossRef]

15. Appleby, M.C.; Weary, D.M.; Chua, B. Performance and feeding behaviour of calves on ad libitum milk from artificial teats. Appl. Anim. Behav. Sci. 2001, 74, 191-201. [CrossRef]

16. Guler, O.; Yanr, M.; Bayram, B. Effect of different milk feeding schedules on the growth and feed conversion efficiencies in Holstein Friesian and Brown Swiss calves. Ind. J. Anim. Sci. 2003, 73, 1278-1280.

17. Nielsen, P.P.; Jensen, M.B.; Lidfors, L. Milk allowance and weaning method affect the use of a computer controlled milk feeder and the development of cross-sucking in dairy calves. Appl. Anim. Behav. Sci. 2008, 109, 223-237. [CrossRef]

18. Shamay, A.; Werner, D.; Moallem, U.; Barash, H.; Bruckental, I. Effect of nursing management and skeletal size at weaning on puberty, skeletal growth rate, and milk production during first lactation of dairy heifers. J. Dairy Sci. 2005, 88, 1460-1469. [CrossRef]

19. Moallem, U.; Werner, D.; Lehrer, H.; Zachut, M.; Livshitz, L.; Yakoby, S.; Shamay, A. Long-term effects of ad libitum whole milk prior to weaning and prepubertal protein supplementation on skeletal growth rate and first-lactation milk production. J. Dairy Sci. 2010, 93, 2639-2650. [CrossRef] [PubMed]

20. Rushen, J.; De Passillé, A.M. Behaviour, welfare and productivity of dairy cattle. Can. J Anim. Sci. 1998, 78, 3-21.

21. Grøndahl, A.M.; Skancke, E.M.; Mejdell, C.M.; Jansen, J.H. Growth rate, health and welfare in a dairy herd with natural suckling until 6-8 weeks of age: A case report. Acta Vet. Scand. 2007, 49, 16. [CrossRef]

22. Paula Vieira de, A.; De Passillé, A.M.; Weary, D.M. Effects of the early social environment on behavioral responses of dairy calves to novel events. J. Dairy Sci. 2012, 95, 5149-5155. [CrossRef]

23. Costa, J.H.C.; Meagher, R.K.; Von Keyserlingk, M.A.G.; Weary, D.M. Early pair housing increases solid feed intake and weight gains in dairy calves. J. Dairy Sci. 2015, 98, 6381-6386. [CrossRef] [PubMed]

24. Khan, M.A.; Weary, D.M.; von Keyserlingk, M.A.G. Effects of milk ration on solid feed intake, weaning, and performance in dairy heifers. J. Dairy Sci. 2011, 94, 1071-1081. [CrossRef] [PubMed]

25. Tao, S.; Monteiro, A.P.A.; Thompson, I.M.; Hayen, M.J.; Dahl, G.E. Effect of late-gestation maternal heat stress on growth and immune function of dairy calves. J. Dairy Sci. 2012, 95, 7128-7136. [CrossRef] [PubMed]

26. Monteiro, A.P.A.; Tao, S.; Thompson, I.M.T.; Dahl, G.E. In utero heat stress decreases calf survival and performance through the first lactation. J. Dairy Sci. 2016, 99, 8443-8450. [CrossRef]

27. Collier, R.J.; Baumgard, L.H.; Zimbelman, R.B.; Xiao, Y. Heat stress: Physiology of acclimation and adaptation. Anim. Front. 2018, 9, 12-19. [CrossRef] [PubMed]

28. Dahl, G.E.; Tao, S.; Laporta, J. Heat stress impacts immune status in cows across the life cycle. Front. Vet. Sci. 2020, 7, 116. [CrossRef] [PubMed]

29. Herbut, P.; Angrecka, S.; Walczak, J. Environmental parameters to assessing of heat stress in dairy cattle-A review. Int. J. Biometeorol. 2018, 62, 2089-2097. [CrossRef] [PubMed] 
30. Graham, J.M., Jr.; Edwards, M.J.; Edwards, M.J. Gestational effects of maternal hyperthermia due to febrile illnesses and resultant patterns of defects in humans. Teratology 1998, 58, 209-221. [CrossRef]

31. Illek, J.; Kumprechtova, D.; Matejicek, M.; Vlcek, M. Metabolic profile in high-producing dairy cows in different phases of the calving-to-calving interval. Folia Veter. 2009, 53 (Suppl. 1), 73-74.

32. Greenwood, P.L.; Thompson, A.N.; Ford, S.P. Postnatal consequences of the maternal environment and of growth during prenatal life for productivity of ruminants. In Managing the Prenatal Environment to Enhance Livestock Productivity; Greenwood, P.L., Bell, A.W., Vercoe, P.E., Viljoen, G.J., Eds.; Springer: Dordrecht, The Netherlands, 2010; pp. 3-36. [CrossRef]

33. Tao, S.; Dahl, G.E. Heat stress effects during late gestation on dry cows and their calves. J. Dairy Sci. 2013, 96, 4079-4093. [CrossRef]

34. Mellado, M.; Lopez, E.; Veliz, F.G.; De Santiago, M.H.; Macias-Cruz, U.; Avendaño-Reyes, L.; Garcia, J.E. Factors associated with neonatal dairy calf mortality in a hot-arid environment. Livest. Sci. 2014, 159, 149-155. [CrossRef]

35. Collier, R.J.; Gebremedhin, K.G. Thermal biology of domestic animals. Annu. Rev. Anim. Biosci. 2015, 3, 513-532. [CrossRef]

36. Johnson, J.S.; Abuajamieh, M.; Sanz Fernandez, M.V.; Seibert, J.T.; Stoakes, S.K.; Nteeba, J.; Keating, A.F.; Ross, J.W.; Rhoads, R.P.; Baumgard, L. Thermal stress alters postabsorptive metabolism during pre- and postnatal development. In Climate Change Impact on Livestock: Adaptation and Mitigation, Chapter 5; Sejian, V., Gaughan, J., Baumgard, L., Prasad, C., Eds.; Springer: New Delhi, India, 2015; pp. 61-80. [CrossRef]

37. Herbut, P.; Angrecka, S.; Godyń, D.; Hoffmann, G. The physiological and productivity effects of heat stress in cattle-A review. Ann. Anim. Sci. 2019, 19, 579-594. [CrossRef]

38. Monteiro, A.P.A.; Guo, J.R.; Weng, X.S.; Ahmed, B.M.; Hayen, M.J.; Dahl, G.E.; Bernard, J.K.; Tao, S. Effect of maternal heat stress during the dry period on growth and metabolism of calves. J. Dairy Sci. 2016, 99, 3896-3907. [CrossRef]

39. Laporta, J.; Fabris, T.F.; Skibiel, A.L.; Powell, J.L.; Hayen, M.J.; Horvath, K.; Miller-Cushon, E.K.; Dahl, G.E. In utero exposure to heat stress during late gestation has prolonged effects on the activity patterns and growth of dairy calves. J. Dairy Sci. 2017, 100, 2976-2984. [CrossRef] [PubMed]

40. Pinedo, P.J.; De Vries, A. Season of conception is associated with future survival, fertility, and milk yield of Holstein cows. J. Dairy Sci. 2017, 100, 6631-6639. [CrossRef] [PubMed]

41. Recce, S.; Huber, E.; Notaro, U.S.; Rodríguez, F.M.; Ortega, H.H.; Rey, F.; Signorini, M.L.; Salvetti, N.R. Association between heat stress during intrauterine development and the calving-to-conception and calving-to-first-service intervals in Holstein cows. Theriogenology 2021, 162, 95-104. [CrossRef]

42. Broucek, J.; Uhrincat, M.; Kisac, P.; Hanus, A. Effect of different rearing during the milk-feeding period on growth of dairy calves. Agriculture 2020, 10, 346. [CrossRef]

43. De Passillé, A.M.; Rushen, J. Calves' behaviour during nursing is affected by feeding motivation and milk availability. Appl. Anim. Behav. Sci. 2006, 101, 264-275. [CrossRef]

44. Petrikovic, P.; Sommer, A. Requirement of Nutrients for Cattle, 2nd ed.; Publication of VUZV: Nitra, Slovakia, $2002 ;$ p. 62.

45. McGuirk, S.M. Disease management of dairy calves and heifers. Vet. Clin. North Am. Food Anim. Pract. 2008, 24, 139-153. [CrossRef] [PubMed]

46. Slavik, P.; Illek, J.; Brix, M.; Musilova, L.; Rajmon, R.; Klabanova, P.; Jilek, F. Health status of beef cows and their calves in the Czech Republic. Acta Veter. Brno 2009, 78, 47-56. [CrossRef]

47. Novak, P.; Vokralova, J.; Tittl, K.; Mala, G.; Illek, J. Selected aspects of welfare and prevention of disease in ruminants. Veterinarstvi 2010, 60, 25-27.

48. Stevenson, J.S. Reproductive management of dairy cows in high milk-producing herds. J. Dairy Sci. 2001, 84 (Suppl. E), E128-E143. [CrossRef]

49. Masello, M.; Perez, M.M.; Granados, G.E.; Stangaferro, M.L.; Ceglowski, B.; Thomas, M.J.; Giordano, J.O. Reproductive performance of replacement dairy heifers submitted to first service with programs that favor insemination at detected estrus, timed artificial insemination, or a combination of both. J. Dairy Sci. 2019, 102, 1671-1681. [CrossRef]

50. Howlader, M.M.R.; Rahman, M.M.; Hossain, M.G.; Hai, M.A. Factors affecting conception rate of dairy cows following artificial insemination in selected area at sirajgonj district of Bangladesh. Biomed. J. Sci. Technol. Res. 2019, 13, 9907-9914.

51. Moran, J.B. Rearing Young Stock on Tropical Dairy Farms in Asia; CSIRO Publishing: Clayton, Australia, $2012 ;$ p. 296.

52. Krohn, C.C.; Foldager, J.; Mogensen, L. Long-term effect of colostrum feeding methods on behaviour in female dairy calves. Acta Agric. Scand. Sect. A Anim. Sci. 1999, 49, 57-64. [CrossRef]

53. Bar-Peled, U.; Robinzon, B.; Maltz, E.; Tagari, H.; Folman, Y.; Bruckental, I.; Voet, H.; Gacitua, H.; Lehrer, A.R. Increased weight gain and effects on production parameters of Holstein heifer calves that were allowed to suckle from birth to six weeks of age. J. Dairy Sci. 1997, 80, 2523-2528. [CrossRef]

54. Soberon, F.; Raffrenato, E.; Everett, R.W.; Van Amburgh, M.E. Preweaning milk replacer intake and effects on long-term productivity of dairy calves. J. Dairy Sci. 2012, 95, 783-793. [CrossRef]

55. Asheim, L.J.; Johnsen, J.F.; Havrevoll, Ø.; Mejdell, C.M.; Grøndahl, A.M. The economic effects of suckling and milk feeding to calves in dual purpose dairy and beef farming. Rev. Agric. Food Environ. Stud. 2016, 97, 225-236. [CrossRef]

56. Davis, C.L.; Drackley, J.K. The Development, Nutrition, and Management of the Young Calf, 1st ed.; Iowa State University Press: Ames, IO, USA, 1998. 
57. Wójcik, J.; Pilarczyk, R.; Bilska, A.; Weiher, O.; Sanftleben, P. Performance and health of group-housed calves kept in Igloo calf hutches and calf barn. Pak. Vet. J. 2013, 33, 175-178.

58. Jensen, M.B.; Duve, L.R.; Weary, D.M. Pair housing and enhanced milk allowance increase play behavior and improve performance in dairy calves. J. Dairy Sci. 2015, 98, 2568-2575. [CrossRef]

59. Flower, F.C.; Weary, D.M. Effects of early separation on the dairy cow and calf: 2. separation at 1 day and 2 weeks after birth. Appl. Anim. Behav. Sci. 2001, 70, 275-284. [CrossRef]

60. Kisac, P.; Broucek, J.; Uhrincat, M.; Hanus, A. Effect of weaning calves from mother at different ages on their growth and milk yield of mothers. Czech J. Anim. Sci. 2011, 56, 261-268. [CrossRef]

61. Lee, H.J.; Khan, M.A.; Lee, W.S.; Yang, S.H.; Kim, S.B.; Kee, K.S.; Ha, J.K.; Choi, J.K. Influence of equalizing the gross composition of milk replacer to that of whole milk on the performance of Holstein calves. J. Anim. Sci. 2009, 87, 1129-1137. [CrossRef] [PubMed]

62. Miller-Cushon, E.K.; Bergeron, R.; Leslie, K.E.; DeVries, T.J. Effect of milk feeding level on development of feeding behavior in dairy calves. J. Dairy Sci. 2013, 96, 551-564. [CrossRef]

63. Yavuz, E.N.; Todorov, N.; Ganchev, G.; Nedelkov, K. The effect of feeding different milk programs on dairy calf growth, health and development. Bulg. J. Agric. Sci. 2015, 21, 384-393.

64. Johnsen, J.F.; Holmoy, I.H.; Nodtvedt, A.; Mejdell, C.M. A survey of pre-weaning calf management in Norwegian dairy herds. Acta. Vet. Scand. 2021, 63, 20. [CrossRef] [PubMed]

65. Van Eetvelde, M.; Kamal, M.M.; Vandaele, L.; Opsomer, G. Season of birth is associated with first-lactation milk yield in Holstein Friesian cattle. Animal 2017, 11, 2252-2259. [CrossRef]

66. Kamal, M.M.; Van Eetvelde, M.; Depreester, E.; Hostens, M.; Vandaele, L.; Opsomer, G. Age at calving in heifers and level of milk production during gestation in cows are associated with the birth size of Holstein calves. J. Dairy Sci. 2014, 97, 5448-5458 [CrossRef]

67. Tao, S.; Monteiro, A.P.A.; Hayen, M.J.; Dahl, G.E. Short communication: Maternal heat stress during the dry period alters postnatal whole-body insulin response of calves. J. Dairy Sci. 2014, 97, 897-901. [CrossRef] [PubMed]

68. Place, N.T.; Heinrichs, A.J.; Erb, H.N. The effects of disease, management, and nutrition on average daily gain of dairy heifers from birth to four months. J. Dairy Sci. 1998, 81, 1004-1009. [CrossRef]

69. Broucek, J.; Kisac, P.; Uhrincat, M.; Hanus, A.; Benc, F. Effect of high temperature on growth performance of calves maintained in outdoor hutches. J. Anim. Feed Sci. 2008, 17, 139-146. [CrossRef]

70. Chester-Jones, H.; Heins, B.J.; Ziegler, D.; Schimek, D.; Schuling, S.; Ziegler, B.; De Ondarza, M.B.; Sniffen, C.J.; Broadwater, N Relationships between early-life growth, intake, and birth season with first-lactation performance of Holstein dairy cows. J. Dairy Sci. 2017, 100, 3697-3704. [CrossRef]

71. Carvalho, M.R.; Aboujaoude, C.; Penagaricano, F.; Santos, J.E.P.; DeVries, T.J.; McBride, B.W. Associations between maternal characteristics and health, survival, and performance of dairy heifers from birth through first lactation. J. Dairy Sci. 2020, 103, 823-839. [CrossRef] [PubMed]

72. Broucek, J.; Kisac, P.; Uhrincat, M. Effect of hot temperatures on the hematological parameters, health and performance of calves. Int. J. Biometeorol. 2009, 53, 201-208. [CrossRef]

73. Illek, J.; Kumprechtova, D.; Kudrna, V.; Matejicek, M.; Vlcek, M. Epidemiology of production diseases in high producing dairy cows on Czech dairy farms. Veterinarstvi 2010, 60, 20-24.

74. Strong, R.A.; Silva, E.B.; Cheng, H.W.; Eicher, S.D. Acute brief heat stress in late gestation alters neonatal calf innate immune functions. J. Dairy Sci. 2015, 98, 7771-7783. [CrossRef]

75. Collier, R.J.; Renquist, B.J.; Xiao, Y. Stress physiology including heat stress. J. Dairy Sci. 2017, 100, 10367-10380. [CrossRef]

76. Novak, P.; Mala, G.; Jarolimkova, A. Animal, housing and nutrition as prerequisite for health, reproduction and production in dairy cattle. In Proceedings of the XIXth Congress International Society of Animal Hygiene, Wroclaw, Poland, 8-12 September 2019; pp. 49-51.

77. Bakony, M.; Jurkovich, V. Heat stress in dairy calves from birth to weaning. J. Dairy Res. 2020, 87, 53-59. [CrossRef]

78. Heinrichs, A.J.; Wells, S.J.; Hurd, H.S.; Hill, G.W.; Dargatz, D.A. The National dairy heifer evaluation project: A profile of heifer management practices in the United States. J. Dairy Sci. 1994, 77, 1548-1555. [CrossRef]

79. Drackley, J.K. Early growth effects on subsequent health and performance of dairy heifers. In Calf and Heifer Rearing; Garnsworthy, P.C., Ed.; Nottingham University Press: Nottingham, UK, 2005; Volume 12, pp. 213-235.

80. Svensson, C.; Hultgren, J.; Oltenacu, P.A. Morbidity in Swedish dairy calves from 3 to 7 months of age, and risk factors for diarrhea and respiratory disease. Prev. Vet. Med. 2006, 74, 162-179. [CrossRef] [PubMed]

81. Beaver, A.; Meagher, R.K.; Von Keyserlingk, M.A.G.; Weary, D.M. A systematic review of the effects of early separation on dairy cow and calf health. J. Dairy Sci. 2019, 102, 5784-5810. [CrossRef] [PubMed]

82. De la Cruz, L.A.; Bonilla-Jaime, H.; Orozco-Gregorio, H.; Tarazona-Morales, A.M.; Ballesteros-Rodea, G.; Roldán-Santiago, P.; Waytula, M.; Vargas-Romero, J. Effects of weaning on the stress responses and productivity of water buffalo in different breeding systems: A review. Livest. Sci. 2019, 226, 73-81. [CrossRef]

83. Banos, G.; Brotherstone, S.; Coffey, M.P. Prenatal maternal effects on body condition score, female fertility, and milk yield of dairy cows. J. Dairy Sci. 2007, 90, 3490-3499. [CrossRef] 
84. Rincker, L.D.; VandeHaar, M.J.; Wolf, C.A.; Liesman, J.S.; Chapin, L.T.; Nielsen, M.W. Effect of intensified feeding of heifer calves on growth, pubertal age, calving age, milk yield, and economics. J. Dairy Sci. 2011, 94, 3554-3567. [CrossRef]

85. Wathes, D.C.; Pollott, G.E.; Johnson, K.F.; Richardson, H.; Cooke, J.S. Heifer fertility and carry over consequences for life time production in dairy and beef cattle. Animal 2014, 8, 91-104. [CrossRef] [PubMed] 